http://nv.nltu.edu.ua

https://doi.org/10.15421/40280110

$@$ Correspondence author

Article received 09.02.2018 p.

Article accepted 28.02.2018 p.

A. V. Vyshnevskyi

удк 630*23:504.73.05

vishnev.tolik@ukr.net

A. V. Vyshnevskyi, V. M. Turko

Zhytomyr National Agroecological University, Zhytomyr, Ukraine

\title{
THE SPREAD OF DISEASES IN VOLYN REGION FORESTS
}

Some peculiarities of expansion characteristics and general dynamics of the forest disease cores in Volyn region were studied in Volyn Regional Forestry and Hunting Industry Administration (VRFHIA). The dynamics of sanitary selective and solid felling with area distributions connected with VRFHIA in 2016 was illustrated. The main problems and tendencies of forest sanitary conditions were explained. The area of lesions the most dangerous forest diseases for 2016 if found to increase by 954.8 ha or $3.8 \%$. Having analysed Volyn region forest sanitary condition the authors have ascertained that generally 1220.5 ha of disease cores were eliminated by means of forest protection activities and written off during the report year. The biggest size is the concentration of Root fungus (Heterobasidion annosum (Fr.) Bref. 1889) and it remained the same as in the previous years. It covers 13961 ha or in other words it is $55 \%$ of general surface of disease cores in this region. 5117 hectares need some methods of felling. Root fungus (Heterobasidion annosum (Fr.) Bref. 1889) has developed rapidly because of the long lasting drought season and the ground water level decrease. During 2016 Volyn RFHIA enterprises tried to solve the problem by solid sanitary felling in the areas of 332 ha with disease concentration. This is $2.4 \%$ of the general land area of these nucleuses. The most common forest diseases are defined to be as follows: stem rot (Fomes fomentarius (L) Fr.1849) - 2363 ha; aspen fungus (Phellinus tremulae (Bondartsev \& P. N. Borisov 1953) - 993 ha; diametrical Oak cancer (Pseudomonas quercus Schern.) - 922 ha; oak fungus (Daedalea quercina (L.) Pers.1801) - 676 ha; birch polyporus (Piptoporus betulinus (Bull.) P. Karst.1881) - 657 ha; red rot (Phellinus pini) - 562 ha; pitch streak (Cronartium flaccidum (Alb. \& Schwein.) G. Winter 1880) - 369 ha; alder fungus (Phellinus igniarius (L.) Quél. 1886) - 313 ha; bacterial ash cancer (Pseudomonas savastanoi (Janse 1982) Gardan, et al., 1992) - 216 ha; much smaller (Armillariella mellea (Vahl) P. Kumm. 1871) 183 ha. In order to protect and preserve forests when forestry proceedings, a complex of sanitary and recreational events and sanitary requirements are taking place.

Keywords: sanitary cuts; wood decay; sanitary condition of the forests; dynamics of diseases and pests; plantings affected by pathogens.

Introduction. Sanitary and sanatory events are the part of preventative measures that take place by the forest users in order to preserve stability of plants, prevention of development of pathological processes in the forest, decrease of damage that is caused by the pests, diseases, natural phenomena and technogenic effects (Manion, 1991; Cherubini et al., 2002). 539.7 ha of disease concentrations faded under the influence of natural factors. 2716.8 ha of new ones arose during the year (Turko et al., 2016).

Health-improving measures are established in order to protect and save forests. Health-improving measures are part of preventive treatment which is to keep the rigidity of forest crops, to prevent the development of pathological processes in the forest, to lower the harmfulness caused by insect pests, diseases, natural calamities and anthropogenic influence (Lonsdale et al., 2008).

Materials and Methods. The research was held on the basis of the standardized document in force and recommendations based on usage of sanitary investigation, the results of forest health monitoring and statistical data of forestry enterprises (Vorontsov, 1978; Sanitarni pravyla u lisakh Ukrainy, 1995; Anonimous, 2015). The general forest cove-

rage in relation to the land area is $34 \%$. The main forest forming species is Pinus sylvestris (L) and it constitutes about $63 \%$ of the forested area, Betula (L.) (about 16\%) and Quercus (L.) (about $7 \%$ ).

The aim of this research is to study the functional features of disease agents' development in planted forests of Volyn RFHIA and to analyze their influence on general sanitary forest state. The object of the research is forest plantations of different ages infected by disease agents.

Results and Discussions. While analyzing the sanitary state of Volyn forests we can see that the dynamics of area, affected by forest pests, diseases and damages by abiotic factors is negative in forest pathological meaning. By the end of 2016 the land areas with the concentration of forest diseases have increased with 957 ha (3.9\%) as compared to the last year and constitutes 25.234 ha.The dynamics of sanitary selective fellings continues decreasing after 2010 (Fig. 1). According to the reported data the biggest amount of cubic meters of selective sanitary fellings was in 2010 and constituted $193.751 \mathrm{~m}^{3}$. In 2015 this number changed to $46.528 \mathrm{~m}^{3}$, which is four times less. The plan of sanitary fellings for 2016 was about $75.000 \mathrm{~m}^{3}$ of wood.

\section{Інформація про авторів:}

Вишневський Анатолій Васильович, канд. с.-г. наук, доцент кафедри таксації лісу та лісовпорядкування.

Email: vishnev.tolik@ukr.net

Турко Василь Миколайович, канд. с.-г. наук, доцент, декан факультету лісового господарства. Email: turkovasyl1964@gmail.com

Цитування за ДСтУ: Vyshnevskyі A. V., Turko V. М. The Spread of Diseases in Volyn Region Forests. Науковий вісник НЛтУ України. 2018, т. 28, № 1. C. 51-54.

Citation APA: Vyshnevskyi, A. V., \& Turko, V. M. (2018). The Spread of Diseases in Volyn Region Forests. Scientific Bulletin of UNFU, 28(1), 51-54. https://doi.org/10.15421/40280110 


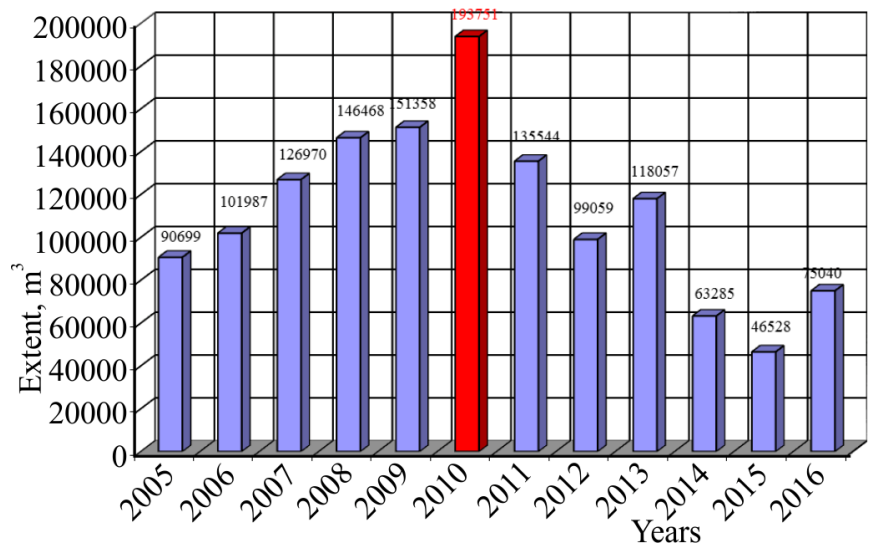

Fig. 1. Dynamics of the timber volume removed by selective sanitary fellings in Volyn RFHIA

Their amounts have significantly declined compared to the plan and constitutes $74 \%$ (cubic measure). While sanitary selective fellings were conducted it was revealed that the selection of cubic measures from 1 hectare has increased with $0.7 \mathrm{~m}^{3} /$ ha in comparison with the previous year.

Since 2005 and up to 2010 the amount of selective sanitary fellings has been continuing to grow. And since 2011 it has been constantly decreasing. By the end of the accounting period the smallest amount of fellings has been registered for the last 10 years. The amount of cubic meters that have been obtained from 1 ha in 2015 has also been the lowest for the last 10 years.

The dynamics of selective sanitary fellings is also characterized by the smallest amount of such ones conducted in the current year for the last 10 years (Fig. 2). And compared to 2009 it has become three times lower and equals 4286 ha. The delivery of this plan accounts for $64 \%$.

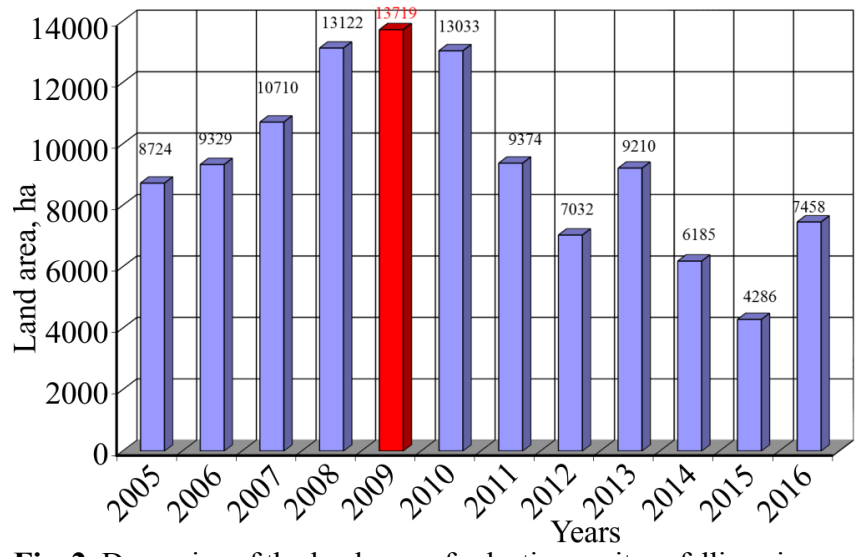

Fig. 2. Dynamics of the land area of selective sanitary fellings in Volyn RFHIA

The amount of solid sanitary fellings in 2015 is 1821 ha, which has reached the maximum point for the last 10 years (Fig. 3). Volyn region climate conditions are characterized by moderate continental climate with warm summers and mild winters, which is generally beneficial to the growth and development of the forests. The major factor of the deterioration in the condition of the forests and the decrease in forest expansion are weather changes. They became the cause of extreme climate conditions (drought or lowering of ground water level) which are frequent. The average precipitation level has decreased with $2.5 \%$, and the annual amount of effective temperatures with $1.7 \%$ for the last 20 years (Vyshnevsky, 2014).

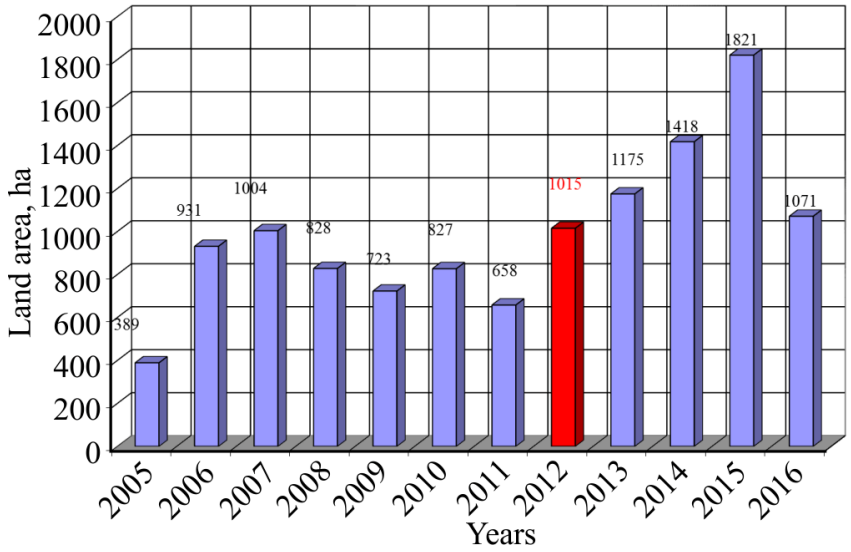

Fig. 3. Dynamics of the land area of solid sanitary fellings in Volyn RFHIA

There are several major reasons of forest crops plantation for selective sanitary fellings. Firstly, fires of the last years $-21.2 \%$. Secondly, a root fungus (Heterobasidion annosum) $-18 \%$. Thirdly, the fire in $2015-17 \%$. Also, minor flooding, marshiness, too much humidity, groundwater level fluctuation. Among other reasons there are diseases of forest plantations which provoke stem rot. Area distribution of solid sanitary fellings caused by different diseased and damages in Volyn RFHIA - $4.2 \%$ windfall, $1.3 \%$ honey mushroom, $1.8 \%$ red rot, $18 \%$ pine fungus, $7.6 \%$ minor flooding, $21.2 \%$ fires of the last years, $8.4 \%$ groundwater level decrease, $1.9 \%$ disfunctions caused by agricultural activities, $8.9 \%$ groundwater level fluctuation, $8.4 \%$ other reasons, $16.9 \%$ fir fungus (Fig. 4).

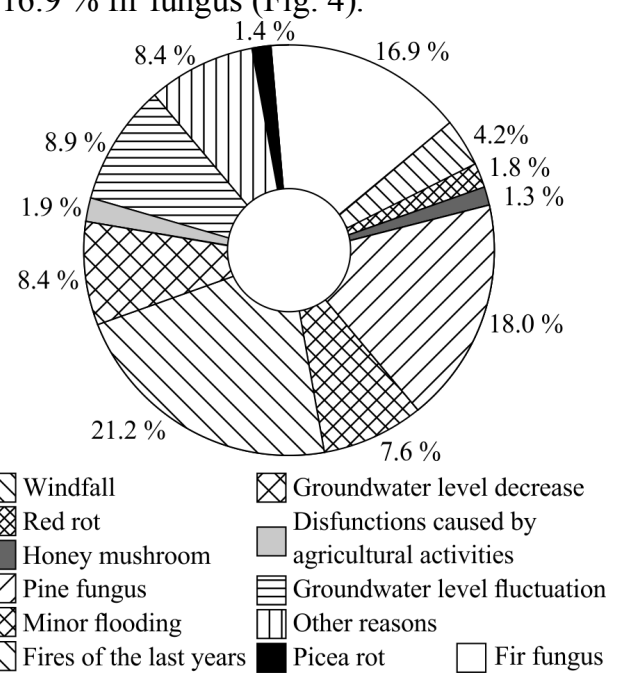

Fig. 4. Area distribution of solid sanitary fellings caused by different diseases and damages in Volyn RFHIA

Insect pests are not taken into account because their amount is low and doesn't influence the research. The largest land area of fellings was held because of the fire reasons in the current year. Also the major factor is that the present year is characterized by the drought season. The increase of disease concentrations in the forest occurred mainly because of the root fungus nucleus (Heterobasidion annosum). The biggest disease area is a root fungus (Heterobasidion annosum). Its square area in comparison with the previous year has increased to $4.5 \%$ and now it occupies 13.961 ha. In the current year 1590 ha of root fungus nucleus emerged (Heterobasidion annosum), and only 708 were eliminated by sanitary cuts.

This disease is in progression in pure plantations on barren soil. An important factor of the spread of this disease is 
the creation of pine single-crop cultures on previously cultivated land and the critical age of this kind of disease. The crucial negative factor is the lack of attention of forest service to forestry enterprise in project management and sanitary examinations in the places of the low degree of damage. As a result, the massive attack of weakened trees (III IV category of sanitary state) is being observed by hyperparasites which cause negative influence on destabilization of forest pathological situation, especially the forest crops weakened by the root fungus (Heterobasidion annosum).

According to the sanitary examination reported data the biggest locations of root fungus (Heterobasidion annosum) were revealed in State Establishment "Starovyzhivske Forestry Enterprise" - 1665 ha, State establishment "Manevytske forestry enterprise" - 2341 ha, State establishment "Liubeshivske Forestry and Hunting Enterprise" - 970 ha, State establishment "Kamin-Kashyrske forestry enterprise" - 810 ha, State establishment "Liubomolske Forestry Enterprise" - 1223 ha, State establishment "Ratnivske Forestry and Hunting Enterprise" - 882 ha, State establishment "Ratneagrolis" - 799 ha etc.

As well as in previous years, diseases that provoke stem rot - Aspen fungus (Phellinus tremulae (Bondartsev) (Bondartsev \& Borisov, 1953), Birch polyporus (Piptoporus betulinus (Bull.) P. Karst., 1881), Red rot of pine and larch (Phellinus pini (Brot.) Bondartsev \& Singer, 1941), Alder fungus (Phellinus igniarius (L.) Quél., 1886), Oak fungus (Daedalea quercina (L.) Pers. 1801) etc. have become widely spread. As to the data about Oak fungus (Daedalea quercina (L.) Pers. 1801), Birch polyporus (Piptoporus betulinus (Bull.) P. Karst., 1881), Alder fungus (Phellinus igniarius (L.) Quél. 1886), they defeat extraneous substance of main forest breeds where the age of technical ripeness was reached (in some cases it over ripped) and such trees as aspen, birch and alder degenerate.

Concerning the Red rot of pine and larch (Phellinus pi$n i$ ) and Oak fungus (Daedalea quercina (L.) Pers., 1801) the diseases are mainly spread in overriped wood. The age of main usage was prolonged because these forest crops were unexploited.

Aspen fungus (Phellinus tremulae (Bondartsev \& Borisov, 1953) nucleus occupies 993 ha by the end of 2016, where 18 ha need some control measures. Red rot of pine and larch (Phellinus pini) nucleus occupies 562 ha by the end of 2016, where 248 ha need some control measures.

Oak fungus (Daedalea quercina (L.) Pers., 1801) nucleus occupies 676 ha by the end of 2016, where 230 ha need some control measures. Birch polyporus (Piptoporus betulinus (Bull.) P. Karst., 1881) nucleus occupies 657 ha by the end of 2016, where 283 ha need some control measures.

Stem rot (Fomes fomentarius (L.) Fr. 1849) nucleus occupies 2363 ha by the end of 2016, where 892 ha need some control measures. Diametrical Oak cancer (Pseudomonas quercus Schern.) nucleus occupies 922 ha by the end of 2016, where 328 ha need some control measures.

Alder fungus (Phellinus igniarius (L.) Quél., 1886) nucleus occupies 313 ha by the end of 2016, where 137 ha need some control measures. Pitch streak (Cronartium flaccidum (Alb. \& Schwein.) G. Winter, 1880) nucleus occupies 369 ha by the end of 2016, where 92 ha need some control measures.

Bacterial ash cancer (Pseudomonas savastanoi (Janse, 1982) Gardan, et al., 1992) nucleus occupies 216 ha by the end of 2015, where 114 ha need some control measures. Much smaller land area occupy such diseases as honey mushroom (Armillariella mellea (Vahl) P. Kumm., 1871) 183 ha, birch fungus (Lenzites betulina (L.) Fr., 1838) 84 ha etc.

Conclusions. After conducting our research, we can make the following conclusions:

1. The most influential factor on sanitary condition of Volyn forest ranges in 2016 was a long drought season which lead to the decrease of ground water level. The land area of weakened and drying plants has increased. Besides, a major harm was made to the forest plantations by heavy winds that were noted in the middle of the summer during the current year that happened on the territory of north-western forestry enterprises. Also, forest fires and their record square surface was noted and registered in the current year as well.

2. The lack of humidity can be noticed because of the long lasting period of the drought season proportionally on the whole territory of the region. The drought is revealed on small surfaces which is, probably, the result of the land form and the micro-climate where the drought takes place. During the year 2016, 321 ha of forest crops that have perished as a result of the ground water level lowering and the ground water level fluctuation were examined.

3. The drought of tertiary fir forest crops that have reached maximum age is also a global problem which characterizes Volyn forests sanitary state. This problem is mostly visible in southern forest regional enterprises. The drought is caused by the damage to the crops that arose as a result of root rot and massive invasion of pests. One of the drought reasons might be the fact that the territory of western Polissia isn't a natural habitat for pure pine tree plantations.

4. Root fungus (Heterobasidion annosum (Fr.) Bref. 1889) has developed rapidly because of the long lasting drought season and the ground water level decrease. During 2016 Volyn RFHIA enterprises tried to solve the problem by solid sanitary fellings in the areas of 332 ha with disease concentration. This is $2.4 \%$ from the general land area of these nucleuses.

\section{Перелік використаних джерел}

Anonimous. (2016). Report materials about the spreading of diseases and pests state DSLP "Rivnelisozahyst". 70 p. [In Ukrainian].

Cherubini, P., Fontana, G., Rigling, D., Dobbertin, M., Brang, P., \& Innes, J. L. (2002). Tree-life history prior to death, two fungal root pathogens affect tree-ring growth differently. Journal of Ecology, 90(5), 839-850. https://doi.org/10.1046/j.1365-2745.2002.00715.x

Lonsdale, D., Pautasso, M., \& Holdenrieder, O. (2008). Wood-decaying fungi in the forest, conservation needs and management options. European Journal of Forest Research 127, 1-22. https://doi.org/10.1007/s10342-007-0182-6

Manion, P. D. (1991). Tree Disease Concepts (2nd ed.). Prentice-Hall, Englewood Cliffs, New Jersey. 402 p.

Sanitarni pravyla u lisakh Ukrainy. (1995). Postanova Kabinetu Ministriv Ukrainy № 555 vid 27 lypnia 1995 r., Kyiv, Ukraine, 20 p.

Turko, V., Vyshnevsky, A., Siruk, Iu., \& Pecheniuk, Iu. (2016). Spreading diseases and pests in the forests of Rivne region. Scientific $\begin{array}{llll}\text { Bulletin of } & \text { 26(5), } & \text { 170-176. }\end{array}$ https://doi.org/10.15421/40260526.

Vorontsov, A. (1978). Forest pathology. Moscow: Forest industry. $270 \mathrm{p}$

Vyshnevsky, A. (2014). Reproduction of Pine Forests under Bor Conditions of Rivnenske Polissia. Scientific Bulletin of UNFU, 23(3), 46-50. [In Ukrainian]. 


\section{ПОШИРЕННЯ ХВОРОБ У ЛІСАХ ВОЛИНСЬКОЇ ОБЛАСТІ}

Розглянуто особливості поширення та динаміку розвитку осередків хвороб у лісах Волинської області. Встановлено, що динаміка осередків хвороб лісу є негативною в лісопатологічному аспекті, а площа осередків найнебезпечніших хвороб лісу за 2016 р. збільшилась на 954,8 га (3,8 \%). Висвітлено основні проблеми та тенденції санітарного стану лісів та наведено характеристику осередків хвороб лісу в межах Волинського ОУЛМГ. Показано динаміку санітарних рубань, вибіркових та суцільних, за останні 10 років та розподіл СРС за причинами розладу в межах Волинського ОУЛМГ. Проаналізувавши санітарний стан лісів Волині, встановлено, що загалом ліквідовано заходами боротьби та списано впродовж звітного року 1220,5 га осередків хвороб, затухли під дією природних факторів 539,7 га осередків хвороб, виникло протягом року 2716,8 га нових осередків. Виявлено, що найбільшим осередком хвороб по площі є коренева губка (Heterobasidion annosum (Fr.) Bref. 1889). Ї̈і площа, порівняно з попередніми роками, збільшилась на 4,5 \% і становить 13961 га. У 2016 р. виникло 1590 га осередків кореневої губки, а ліквідовано заходами боротьби 708 га. Встановлено, що досить поширеними хворобами по площі в лісах області є, стовбурова гниль (Fomes fomentarius (L) Fr.1849) - 2363 га; осиковий трутовик (Phellinus tremulae (Bondartsev \& Borisov, 1953) - 993 га; поперечний рак дуба (Pseudomonas quercus Schern.) - 922 га; несправжній дубовий трутовик (Daedalea quercina (L.) Pers.1801) - 676 га; березова губка (Piptoporus betulinus (Bull.) - 657 га.

Ключові слова, санітарно-оздоровчі заходи; санітарні рубання; санітарний стан; уражені патогенами насадження.

А. В. Вишневский, В. Н. Турко Житомирский национальный агроэкологический университет, г. Житомир, Украина

\section{РАСПРОСТРАНЕНИЕ БОЛЕЗНЕЙ В ЛЕСАХ ВОЛЫНСКОЙ ОБЛАСТИ}

Рассмотрены особенности распространения и динамика развития очагов болезней в лесах Волынской области. Отмечено, что динамика очагов болезней леса является отрицательной в лесопатологическом отношении, а площадь очагов наиболее опасных болезней леса за 2016 г. увеличилась на 954,8 га (3,8 \%). Освещены основные проблемы и тенденции санитарного состояния лесов и дана характеристика очагов болезней леса в разрезе Волынского ОУЛМГ. Показана динамика выборочных санитарных рубок и сплошных за последние 10 лет и распределение СРС по причинам расстройства в разрезе Волынского ОУЛМГ. Проанализировав санитарное состояние лесов Волыни, установлено, что в общем ликвидировано мерами борьбы и списано в течение отчетного года 1220,5 га очагов болезней, затухли под действием естественных факторов 539,7 га очагов болезней, возникло в течение года 2716,8 га новых очагов. Выявлено, что наибольшим средоточием болезней по площади является корневая губка (Heterobasidion annosum (Fr.) Bref. 1889). Ее площадь, по сравнению с предыдущими годами, увеличилась на 4,5 \% и составляет 13961 га. В 2016 г. возникло 1590 га очагов корневой губки, а ликвидировано мерами борьбы 708 га. Установлено, что наиболее распространенными болезнями по площади в лесах области также являются, стволовая гниль (Fomes fomentarius (L) Fr.1849) - 2363 га; осиновый трутовик (Phellinus tremulae (Bondartsev \& P. N. Borisov 1953) - 993 га; поперечный рак дуба (Pseudomonas quercus Schern.) - 922 га; ложный дубовый трутовик (Daedalea quercina (L.) Pers.1801) - 676 га; березовая губка (Piptoporus betulinus (Bull.) - 657 га.

Ключевые слова: санитарно-оздоровительные мероприятия; санитарные рубки; санитарное состояние; пораженные патогенами насаждения. 